\title{
Mitigating SARS-CoV-2 Transmission in Hospitals: A Systematic Literature Review
}

\author{
Chester Yan Hao $\mathrm{Ng}^{1}$, Nicole-Ann Lim $^{1}$, Lena X. Y. Bao ${ }^{1}$, Amy M. L. Quek ${ }^{1}$ and \\ Raymond C. S. Seet ${ }^{1,2 *}$
}

${ }^{1}$ Department of Medicine, Yong Loo Lin School of Medicine, National University of Singapore, Singapore, Singapore, ${ }^{2}$ Healthy Longevity Translational Research Program, Yong Loo Lin School of Medicine, National University of Singapore, Singapore, Singapore

Objectives: Hospital outbreaks of SARS-CoV-2 infection are dreaded but preventable catastrophes. We review the literature to examine the pattern of SARS-CoV-2 transmission in hospitals and identify potential vulnerabilities to mitigate the risk of infection.

Methods: Three electronic databases (PubMed, Embase and Scopus) were searched from inception to July 27, 2021 for publications reporting SARS-CoV-2 outbreaks in hospital. Relevant articles and grey literature reports were hand-searched.

Results: Twenty-seven articles that described 35 SARS-CoV-2 outbreaks were included. Despite epidemiological investigations, the primary case could not be identified in $37 \%$ of

OPEN ACCESS

Edited by: Sarah Mantwill, University of Lucerne, Switzerland

Reviewed by: Katarina Braun, University of Wisconsin-Madison, United States Gage Moreno, Broad Institute, United States

${ }^{*}$ Correspondence: Raymond C. S. Seet raymond_seet@nus.edu.sg

This Systematic Review is part of the PHR Special Issue "COVID-19: Guidance From Research for Policy and Practice"

Received: 01 November 2021 Accepted: 19 January 2022

Published: 23 February 2022

Citation:

Ng CYH, Lim N-A, Bao LXY, Quek AML and Seet RCS (2022) Mitigating SARS-

CoV-2 Transmission in Hospitals: A

Systematic Literature Review.

Public Health Rev 43:1604572.

doi: 10.3389/phrs.2022.1604572 outbreaks. Healthcare workers accounted for $40 \%$ of primary cases (doctors $17 \%$, followed by ancillary staff $11 \%$ ). Mortality among infected patients was approximately $15 \%$. By contrast, none of the infected HCWs died. Several concerning patterns were identified, including infections involving ancillary staff and healthcare worker infections from the community and household contacts.

Conclusion: Continuous efforts to train-retrain and enforce correct personal protective equipment use and regular routine screening tests (especially among ancillary staff) are necessary to stem future hospital outbreaks of SARS-CoV-2.

Keywords: COVID-19, SARS-CoV-2, hospital outbreaks, nosocomial spread, infection control

\section{INTRODUCTION}

The SARS-CoV-2 virus has inflicted a global health crisis, infecting at least 271 million individuals and causing over 5.3 million deaths as of December 18, 2021 [1]. Compared with other coronaviruses (mainly SARS-CoV and MERS-CoV), the SARS-CoV-2 virus is highly transmissible especially in unvaccinated and immunologically naïve populations $[2,3]$. Despite causing a largely asymptomatic and mild disease, COVID-19 infection could lead to multi-organ damage, pneumonia and death, especially among unvaccinated elderly individuals with multiple comorbidities [4]. Early during this pandemic, uncertainties surrounding the mode of transmission and scarcity in personal protective equipment (PPE) supplies [5] contributed to high rates of infections in countries worldwide. Healthcare systems were continuously strained by the need to care for more severe COVID-19 patients, whilst ensuring the medical needs for existing patients with other acute and chronic medical illnesses are not compromised [6]. A large prospective cohort study of over 2 million individuals in 
the United States and United Kingdom observed a 12-fold increase in risk of SARS-CoV-2 infection involving frontline healthcare workers (HCWs) compared to community individuals, with inpatient HCWs in particular facing an even greater 24-fold increase in risk [7]. Frontline HCWs with direct contact with patients (e.g., doctors, nurses and allied health personnel) were subjected to significant work-related fatigue from caring for their patients for prolonged hours and for continuously being in a state of heightened alert [8]. Countries with more developed healthcare systems (e.g., the United States, Italy and Spain) also witnessed high infection rates. In the first few months of the pandemic, a sero-surveillance study involving over 6,000 Spanish HCWs identified 662 individuals (11.0\%) with SARS-CoV-2 seropositivity [9]. In Taiwan and Singapore where enforcement of nationwide restrictions initially kept infections at a very low level, a resurgence in cases occurred among their HCWs close to a year after SARS-CoV-2 infection was first detected $[10,11]$. Despite high vaccination rates, a resurgence of SARS-CoV-2 infection was similarly observed among healthcare workers at the University of California San Diego Health [12], coinciding with the emergence of the more transmissible variants of concern [13].

The first silver lining of the pandemic occurred when no infections were reported among 42,322 returning medical staff deployed from various parts of China to assist in the Wuhan outbreak, testifying to the overall efficacy of non-pharmacological interventions (NPI) to prevent nosocomial transmission [14]. NPIs refer to measures aimed at disrupting transmission risks through early isolation and quarantine, physical distancing, use of face masks and hand hygiene [15]. In hospitals, NPI measures mandate the use of PPE (comprising N95 respirators, eye protection, full sleeve gown, and gloves) among frontline HCWs when attending to suspected or confirmed COVID-19 patients and among laboratory staff handling biological samples from these patients. In other clinical settings, PPE use is tiered according to work area, patient-care activity, or procedure performed, prioritizing frontline HCWs such as doctors and nurses [15]. However, despite vaccination and NPI measures [16], outbreaks of SARS-CoV-2 continue to be reported in various healthcare settings. This review aims to systematically examine the pattern of SARS-CoV-2 outbreaks in hospitals and identify vulnerable aspects of our preparedness against future outbreaks.

\section{METHODS}

The Preferred Reporting Items of Systematic Reviews and MetaAnalyses (PRISMA) reporting guideline was used in the synthesis of this review [17]. A literature search of 3 electronic databases (PubMed, Embase and Scopus) was conducted from inception to July 27, 2021. The following keywords were used in combination: (SARS-CoV-2 OR COVID-19 OR 2019-nCoV OR 2019 AND ncov) AND (hospital OR healthcare worker) AND outbreak. The appropriate Medical Subject Heading (MeSH) terms and Emtree terms were used in PubMed and Embase respectively. The exact search strategy is presented in Supplementary Table S1. Only

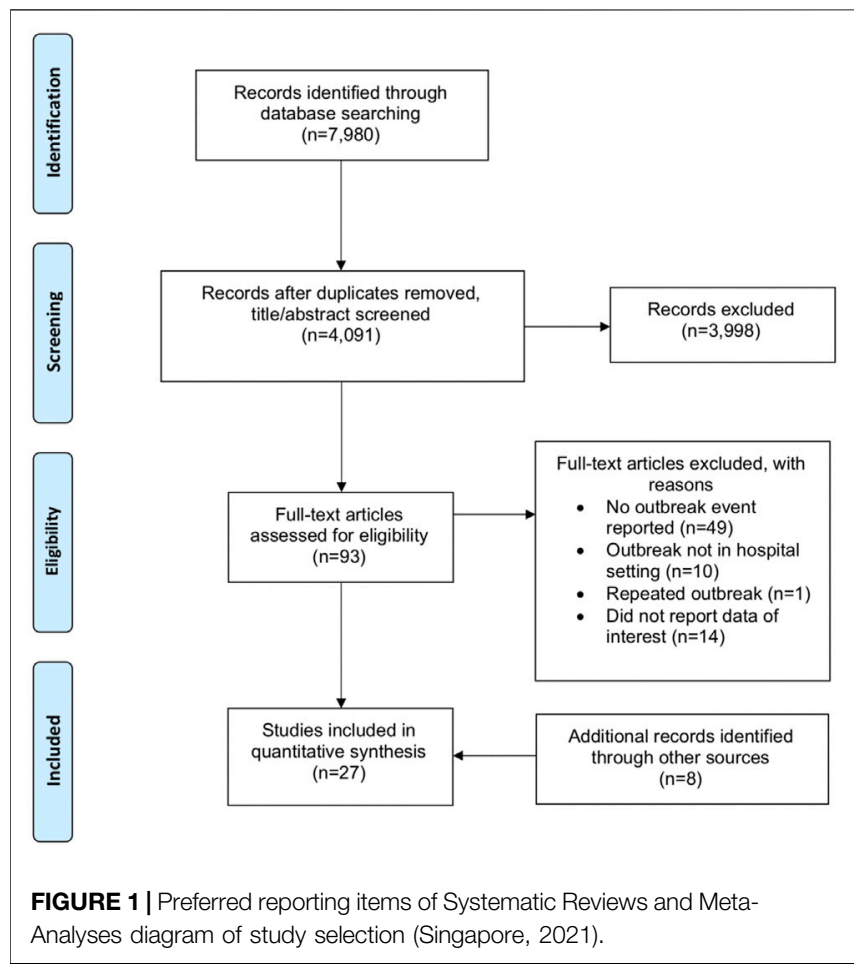

articles written in English were included. In addition, references cited in relevant studies were hand searched and grey literature reports from official sources were identified via web searches.

The articles retrieved from the search were independently screened by two authors and relevant data were extracted, with disagreements resolved by a third senior author. We included any publication types, including full text articles and abstracts, that reported SARS-CoV-2 outbreaks or clusters in hospitals, which were defined as two or more linked cases of COVID-19 within a hospital setting. Data extracted included primary case, detection method and origin of transmission, country of origin, date of first confirmed case, days until no new cases, number of HCWs and patients infected and the respective attack and mortality rates. Key features and learning points of each outbreak were also retrieved. Statistical analysis was performed using $\mathrm{R}$ version 4.0.2 [18]. Proportions are presented in percentages and continuous variables are presented as mean with standard deviation. A PRISMA checklist is included in Supplementary Figure S1.

\section{RESULTS}

A total of 7,980 articles were identified from the initial database search, which was reduced to 4,091 after duplicate publications were removed. Based on the title and abstract, 3,998 articles were excluded. Full text screening further excluded 74 studies. Five additional articles were hand searched from citations and 3 grey literature articles were identified from web searches. Overall, 27 articles reporting 35 outbreaks or clusters were included [10, 11, 19-43]. A flow diagram of the study selection is shown in Figure 1. 
TABLE 1 | Characteristics of SARS-CoV-2 outbreaks in hospitals (Singapore, 2021).

\begin{tabular}{|c|c|c|c|c|c|c|c|c|}
\hline Number & Author & Country & $\begin{array}{c}\text { First } \\
\text { confirmed } \\
\text { case }\end{array}$ & $\begin{array}{l}\text { Primary } \\
\text { case }\end{array}$ & $\begin{array}{l}\text { Detection } \\
\text { method }\end{array}$ & $\begin{array}{l}\text { Origin } \\
\text { of transmission }\end{array}$ & $\begin{array}{l}\text { Days } \\
\text { until } \\
\text { no new } \\
\text { cases }\end{array}$ & Key features \\
\hline 1 & Gao et al [19] & China & $\begin{array}{l}\text { January } \\
2020\end{array}$ & $\begin{array}{l}\text { Unclear, } 2 \\
\text { patients }\end{array}$ & $\begin{array}{l}\text { Symptomatic } \\
\text { testing }\end{array}$ & No prior exposure & $\begin{array}{l}\text { Not } \\
\text { reported }\end{array}$ & $\begin{array}{l}\text { Lack of awareness of NPI } \\
\text { during the early stages of } \\
\text { the pandemic } \\
\text { Atypical presentations of } \\
\text { COVID-19 patients }\end{array}$ \\
\hline 2 & Ji et al. [20] & China & $\begin{array}{l}\text { January } \\
2020\end{array}$ & Unclear & $\begin{array}{l}\text { Symptomatic } \\
\text { testing }\end{array}$ & No prior exposure & $\begin{array}{l}\text { Not } \\
\text { reported }\end{array}$ & $\begin{array}{l}\text { Patients with mental } \\
\text { illness could not } \\
\text { communicate symptoms }\end{array}$ \\
\hline 3 & & South Korea & $\begin{array}{l}\text { February } \\
2020\end{array}$ & $\begin{array}{l}\text { Unclear, likely } \\
\text { patient }\end{array}$ & $\begin{array}{l}\text { Symptomatic } \\
\text { testing }\end{array}$ & No prior exposure & $\begin{array}{l}\text { Not } \\
\text { reported }\end{array}$ & $\begin{array}{l}\text { Psychiatric ward densely } \\
\text { packed with lack of } \\
\text { ventilation and hand } \\
\text { sanitizer }\end{array}$ \\
\hline 4 & Kim et al. [21] & South Korea & $\begin{array}{l}\text { February } \\
2020\end{array}$ & $\begin{array}{l}\text { HCW, patient } \\
\text { transfer staff }\end{array}$ & $\begin{array}{l}\text { Symptomatic } \\
\text { testing }\end{array}$ & No prior exposure & 5 & $\begin{array}{l}\text { Largely minimally } \\
\text { symptomatic or } \\
\text { asymptomatic spread }\end{array}$ \\
\hline 5 & Asad et al. [22] & United Kingdom & Early 2020 & $\begin{array}{l}\text { Unclear, likely } \\
\text { asymptomatic } \\
\text { HCW }\end{array}$ & $\begin{array}{l}\text { Symptomatic } \\
\text { testing }\end{array}$ & No prior exposure & 14 & $\begin{array}{l}\text { Hand hygiene } \\
\text { compliance was } 100 \% \\
\text { within ward but lack of } \\
\text { safe distancing within } \\
\text { ward areas } \\
\text { Largely minimally } \\
\text { symptomatic or } \\
\text { asymptomatic spread }\end{array}$ \\
\hline 6 & $\begin{array}{l}\text { Schwierzeck } \\
\text { et al. [23] }\end{array}$ & Germany & Early 2020 & $\begin{array}{l}\text { HCW, role of } \\
\text { HCW was not } \\
\text { provided }\end{array}$ & $\begin{array}{l}\text { Symptomatic } \\
\text { testing }\end{array}$ & No prior exposure & 4 & $\begin{array}{l}\text { Corroborative findings } \\
\text { that "better positive } \\
\text { predictive values if tests } \\
\text { are performed in } \\
\text { symptomatic individuals" }\end{array}$ \\
\hline 7 & Baker et al. [24] & United States & Early 2020 & Patient & $\begin{array}{l}\text { Symptomatic } \\
\text { testing }\end{array}$ & No prior exposure & $\begin{array}{l}\text { Not } \\
\text { reported }\end{array}$ & $\begin{array}{l}\text { Atypical presentation with } \\
\text { delayed diagnosis of } \\
\text { primary case }\end{array}$ \\
\hline 8 & Harada et al. [25] & Japan & March 2020 & Patient & $\begin{array}{l}\text { Asymptomatic } \\
\text { surveillance }\end{array}$ & $\begin{array}{l}\text { Exposure from } \\
\text { previous hospital }\end{array}$ & $\begin{array}{l}\text { Not } \\
\text { reported }\end{array}$ & $\begin{array}{l}\text { Universal masking and } \\
\text { employee health } \\
\text { screening measures in } \\
\text { place } \\
\text { Largely minimally } \\
\text { symptomatic or } \\
\text { asymptomatic spread }\end{array}$ \\
\hline 9 & $\begin{array}{l}\text { Vanhems } \\
\text { et al. [26] }\end{array}$ & France & March 2020 & $\begin{array}{l}\text { Unclear, } 2 \\
\text { patients }\end{array}$ & $\begin{array}{l}\text { Symptomatic } \\
\text { testing }\end{array}$ & No prior exposure & 8 & Rapid spread of infection \\
\hline 10 & $\begin{array}{l}\text { Luong-Nguyen } \\
\text { et al. [27] }\end{array}$ & France & March 2020 & Unclear & $\begin{array}{l}\text { Symptomatic } \\
\text { testing }\end{array}$ & No prior exposure & $\begin{array}{l}\text { Not } \\
\text { reported }\end{array}$ & $\begin{array}{l}\text { Systemic screening limited } \\
\text { by sensitivity of PCR testing } \\
\text { and viral incubation time } \\
\text { Reduce hospital stay by } \\
\text { utilizing outpatient } \\
\text { services }\end{array}$ \\
\hline 11 & Rickman et al. [28] & United Kingdom & March 2020 & Unclear & $\begin{array}{l}\text { Symptomatic } \\
\text { testing }\end{array}$ & No prior exposure & $\begin{array}{l}\text { Not } \\
\text { reported }\end{array}$ & $\begin{array}{l}\text { In } 32 \% \text { of infections, no } \\
\text { source was identified, } \\
\text { likely from asymptomatic } \\
\text { or undiagnosed patients, } \\
\text { visitors or HCWs }\end{array}$ \\
\hline 12 & Jung et al. [29] & South Korea & March 2020 & Patient & $\begin{array}{l}\text { Symptomatic } \\
\text { testing }\end{array}$ & $\begin{array}{l}\text { Previous contact with } \\
\text { COVID-19 patient }\end{array}$ & (Con & $\begin{array}{l}\text { Transmission from } \\
\text { asymptomatic children to } \\
\text { adults } \\
\text { Successful containment } \\
\text { with extensive contact } \\
\text { tracing and testing } \\
\text { nued on following page) }\end{array}$ \\
\hline
\end{tabular}


TABLE 1 | (Continued) Characteristics of SARS-CoV-2 outbreaks in hospitals (Singapore, 2021).

\begin{tabular}{|c|c|c|c|c|c|c|c|c|}
\hline Number & Author & Country & $\begin{array}{c}\text { First } \\
\text { confirmed } \\
\text { case }\end{array}$ & $\begin{array}{l}\text { Primary } \\
\text { case }\end{array}$ & $\begin{array}{l}\text { Detection } \\
\text { method }\end{array}$ & $\begin{array}{c}\text { Origin } \\
\text { of transmission }\end{array}$ & $\begin{array}{c}\text { Days } \\
\text { until } \\
\text { no new } \\
\text { cases }\end{array}$ & Key features \\
\hline 14 & $\begin{array}{l}\text { Schneider } \\
\text { et al. [31] }\end{array}$ & Germany & March 2020 & $\begin{array}{l}\text { Outbreak 1: } \\
\text { HCW, doctor }\end{array}$ & $\begin{array}{l}\text { Symptomatic } \\
\text { testing }\end{array}$ & No prior exposure & 7 & \multirow{3}{*}{$\begin{array}{l}\text { HCW to HCW } \\
\text { transmission may be a } \\
\text { critical factor in the } \\
\text { spread of COVID-19 } \\
\text { outbreaks in hospitals } \\
\text { and could outweigh the } \\
\text { risks posed by infected } \\
\text { patients }\end{array}$} \\
\hline 15 & & & & $\begin{array}{l}\text { Outbreak 2: } \\
\text { HCW, nurse }\end{array}$ & $\begin{array}{l}\text { Asymptomatic } \\
\text { surveillance }\end{array}$ & No prior exposure & 18 & \\
\hline 16 & & & & $\begin{array}{l}\text { Outbreak 3: } \\
\text { HCW, doctor }\end{array}$ & $\begin{array}{l}\text { Symptomatic } \\
\text { testing }\end{array}$ & No prior exposure & 12 & \\
\hline 19 & Duy et al. [33] & Vietnam & March 2020 & Unclear & $\begin{array}{l}\text { Symptomatic } \\
\text { testing }\end{array}$ & No prior exposure & $\begin{array}{l}\text { Not } \\
\text { reported }\end{array}$ & $\begin{array}{l}\text { Inadequate compliance } \\
\text { to infection control } \\
\text { measures by nonmedical } \\
\text { staff } \\
\text { Whole hospital } \\
\text { quarantine for more than } \\
2 \text { weeks was } \\
\text { implemented } \\
\text { Largely minimally } \\
\text { symptomatic or } \\
\text { asymptomatic spread }\end{array}$ \\
\hline 22 & Biernat et al. [36] & Poland & April 2020 & HCW, nurse & $\begin{array}{l}\text { Symptomatic } \\
\text { testing }\end{array}$ & No prior exposure & $\begin{array}{l}\text { Not } \\
\text { reported }\end{array}$ & $\begin{array}{l}\text { High mortality rate among } \\
\text { hematological patients } \\
\text { with COVID-19 } \\
\text { Asymptomatic } \\
\text { surveillance every } 7 \text { days } \\
\text { for HCWs }\end{array}$ \\
\hline 23 & Borges et al. [37] & Portugal & $\begin{array}{l}\text { August } \\
2020\end{array}$ & Unclear & Admission testing & No prior exposure & 13 & $\begin{array}{l}\text { Largely minimally } \\
\text { symptomatic or } \\
\text { asymptomatic spread } \\
\text { The combination of } \\
\text { epidemiological and } \\
\text { genomic data is beneficial } \\
\text { when investigating } \\
\text { complex outbreaks }\end{array}$ \\
\hline 24 & Dhakal et al. [38] & Nepal & $\begin{array}{l}\text { August } \\
2020\end{array}$ & $\begin{array}{l}\mathrm{HCW} \text {, } \\
\text { nonclinical staff }\end{array}$ & $\begin{array}{l}\text { Symptomatic } \\
\text { testing }\end{array}$ & No prior exposure & (Cont & $\begin{array}{l}\text { Outbreak despite strict } \\
\text { masking, hand hygiene } \\
\text { and education } \\
\text { Continued expansion of } \\
\text { telerehabilitation capacity } \\
\text { inued on following page) }\end{array}$ \\
\hline
\end{tabular}


TABLE 1 | (Continued) Characteristics of SARS-CoV-2 outbreaks in hospitals (Singapore, 2021).

\begin{tabular}{|c|c|c|c|c|c|c|c|c|}
\hline Number & Author & Country & $\begin{array}{c}\text { First } \\
\text { confirmed } \\
\text { case }\end{array}$ & $\begin{array}{l}\text { Primary } \\
\text { case }\end{array}$ & $\begin{array}{l}\text { Detection } \\
\text { method }\end{array}$ & $\begin{array}{c}\text { Origin } \\
\text { of transmission }\end{array}$ & $\begin{array}{c}\text { Days } \\
\text { until } \\
\text { no new } \\
\text { cases }\end{array}$ & Key features \\
\hline 25 & Klompas et al. [39] & United States & $\begin{array}{l}\text { September } \\
2020\end{array}$ & Patient & $\begin{array}{l}\text { Symptomatic } \\
\text { testing }\end{array}$ & No prior exposure & 20 & $\begin{array}{l}\text { Surgical masks can } \\
\text { reduce but not fully } \\
\text { eliminate aerosol and viral } \\
\text { exposure } \\
\text { Multiple sets of infected } \\
\text { roommates even without } \\
\text { infected staff intermediary }\end{array}$ \\
\hline 26 & Selhorst et al. [40] & Belgium & $\begin{array}{l}\text { September } \\
2020\end{array}$ & Patient & $\begin{array}{l}\text { Symptomatic } \\
\text { testing }\end{array}$ & No prior exposure & 5 & $\begin{array}{l}\text { Reinfection in HCW after } \\
\text { primary infection despite } \\
\text { significant neutralizing } \\
\text { antibodies }\end{array}$ \\
\hline 27 & Lee et al. [41] & South Korea & $\begin{array}{l}\text { November } \\
2020\end{array}$ & HCW, doctor & $\begin{array}{l}\text { Symptomatic } \\
\text { testing }\end{array}$ & Community contact & $\begin{array}{l}\text { Not } \\
\text { reported }\end{array}$ & $\begin{array}{l}\text { Initial source of infection } \\
\text { was from the community }\end{array}$ \\
\hline 28 & & & & Caregiver & $\begin{array}{l}\text { Screening after } \\
\text { outbreak }\end{array}$ & No prior exposure & $\begin{array}{l}\text { Not } \\
\text { reported }\end{array}$ & $\begin{array}{l}\text { Largely minimally } \\
\text { symptomatic or } \\
\text { asymptomatic spread }\end{array}$ \\
\hline 29 & & & & HCW, doctor & $\begin{array}{l}\text { Screening after } \\
\text { outbreak }\end{array}$ & $\begin{array}{l}\text { Wife's family tested } \\
\text { positive }\end{array}$ & $\begin{array}{l}\text { Not } \\
\text { reported }\end{array}$ & $\begin{array}{l}\text { Hand hygiene and mask } \\
\text { wearing compliance } \\
\text { variable }\end{array}$ \\
\hline 30 & Cheng et al. [42] & $\begin{array}{l}\text { Hong Kong, } \\
\text { China }\end{array}$ & $\begin{array}{l}\text { December } \\
2020\end{array}$ & Patient & $\begin{array}{l}\text { Symptomatic } \\
\text { testing }\end{array}$ & No prior exposure & 9 & $\begin{array}{l}\text { Primary case not picked } \\
\text { up on admission testing } \\
\text { Likely airborne } \\
\text { transmission with no air } \\
\text { exhaust grilles inside } \\
\text { semi-enclosed patient } \\
\text { cubicles }\end{array}$ \\
\hline 31 & $\begin{array}{l}\text { Akhmetzhanova } \\
\text { et al. [11] }\end{array}$ & Taiwan & $\begin{array}{l}\text { January } \\
2021\end{array}$ & Patient & $\begin{array}{l}\text { Symptomatic } \\
\text { testing }\end{array}$ & Positive travel history & 26 & $\begin{array}{l}\text { Outbreak despite strict } \\
\text { measures including mask } \\
\text { wearing } \\
\text { Epsilon variant detected } \\
\text { in subset of cases }\end{array}$ \\
\hline 32 & $\begin{array}{l}\text { Ministry of Health, } \\
\text { Singapore [10] }\end{array}$ & Singapore & April 2021 & $\begin{array}{l}\text { Unclear, likely } \\
\text { HCW, nurse }\end{array}$ & $\begin{array}{l}\text { Symptomatic } \\
\text { testing }\end{array}$ & No prior exposure & 13 & $\begin{array}{l}\text { Outbreak originated from } \\
\text { Delta variant } \\
\text { breakthrough infection in } \\
\text { vaccinated HCWs, } \\
\text { including cleaners and } \\
\text { porters }\end{array}$ \\
\hline 33 & & Singapore & June 2021 & HCW, porter & $\begin{array}{l}\text { Asymptomatic } \\
\text { surveillance }\end{array}$ & No prior exposure & 12 & $\begin{array}{l}\text { Large scale ringfencing } \\
\text { and quarantining of } \\
\text { contacts, lockdown of } \\
\text { affected wards and } \\
\text { restriction on new } \\
\text { admissions }\end{array}$ \\
\hline 34 & $\begin{array}{l}\text { World Health } \\
\text { Organization [43] }\end{array}$ & Vietnam & May 2021 & HCW, doctor & Travel testing & No prior exposure & $\begin{array}{l}\text { Not } \\
\text { reported }\end{array}$ & $\begin{array}{l}\text { Breakthrough infections } \\
\text { among vaccinated } \\
\text { HCWs, including cleaners }\end{array}$ \\
\hline 35 & & Vietnam & May 2021 & Patient & $\begin{array}{l}\text { Asymptomatic } \\
\text { surveillance }\end{array}$ & $\begin{array}{l}\text { Exposure from } \\
\text { previous hospital }\end{array}$ & 26 & $\begin{array}{l}\text { Significant spread of } \\
\text { infection to patients }\end{array}$ \\
\hline
\end{tabular}

COVID-19, coronavirus disease 2019; HCW, healthcare worker; NPI, non-pharmacological interventions; PCR, polymerase chain reaction.

\section{Outbreak Characteristics}

Thirty-five SARS-CoV-2 outbreaks occurring in 32 hospitals were included. Seven occurred in Germany, 6 in South Korea, 3 each in the United States, China and Vietnam, 2 each in Singapore, the United Kingdom and France, and 1 each from Japan, South Africa, Poland, Portugal, Nepal, Belgium and Taiwan. The outbreaks occurred between January 2020 and June 2021. The mean average time from the first positive individual in the outbreak to no new cases was $18.4( \pm 13.6)$ days.

Earlier outbreaks were characterized by a lack of awareness or implementation of NPI measures [19, 20, 30]. In outbreaks 


\section{Primary Case}

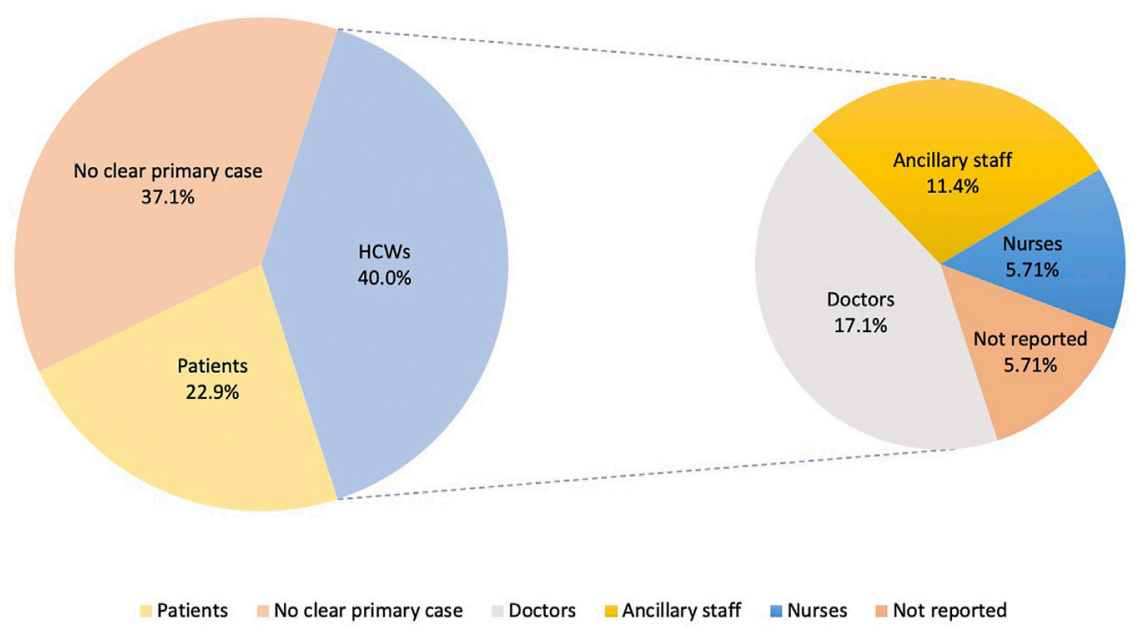

FIGURE 2 | Distribution of primary cases according to healthcare workers, patients and others (Singapore, 2021).

where NPI measures were implemented and enforced, asymptomatic spread as well as missed or delayed diagnosis of primary cases originating from community transmission led to uncontrolled nosocomial spread [22, 25]. Outbreaks in Germany and South Korea later in the pandemic identified HCW households in particular as likely sources of infection $[35,41]$. Selhorst et al. reported reinfection in a HCW despite significant neutralizing antibodies [40] while outbreaks in Singapore and Taiwan resulted from transmission of Delta and Epsilon variant strains among HCWs respectively $[10,11]$. Four outbreaks, occurring in Singapore and Vietnam, involved HCWs who were vaccinated $[10,43]$. Eleven (31.4\%) outbreaks included in the review highlighted lapses in adherence to NPI measures as a potential reason for the outbreak [19, 20, 24, $30-35,39,41]$. However, the use of genomic sequencing to establish links between SARS-CoV-2 cases was only described in 4 outbreaks $[32,37,40,42]$. Detailed information and key features of each outbreak are summarized in Table $\mathbf{1 .}$

\section{Primary Case}

Primary cases are defined in this study as the first infected person to bring SARS-CoV-2 infection into the hospital setting [44]. In $14(40.0 \%)$ of the outbreaks the primary case was a HCW, of whom 6 (17.1\%) were doctors, 4 (11.4\%) were ancillary staff (either patient transfer staff, room service ambassador, nonclinical staff, or porter), 2 (5.71\%) were nurses. The roles of the remaining $2(5.71 \%) \mathrm{HCW}$ primary cases were not provided in the primary publications. Eight $(22.9 \%)$ of the outbreaks were attributed to a patient primary case and in $13(37.1 \%)$ outbreaks no clear primary case was reported. Twenty-seven $(77.1 \%)$ of the outbreaks were detected from symptomatic testing, 4 (11.4\%) from asymptomatic surveillance, 2 (5.71\%) from screening after

\section{Infection Demographics}

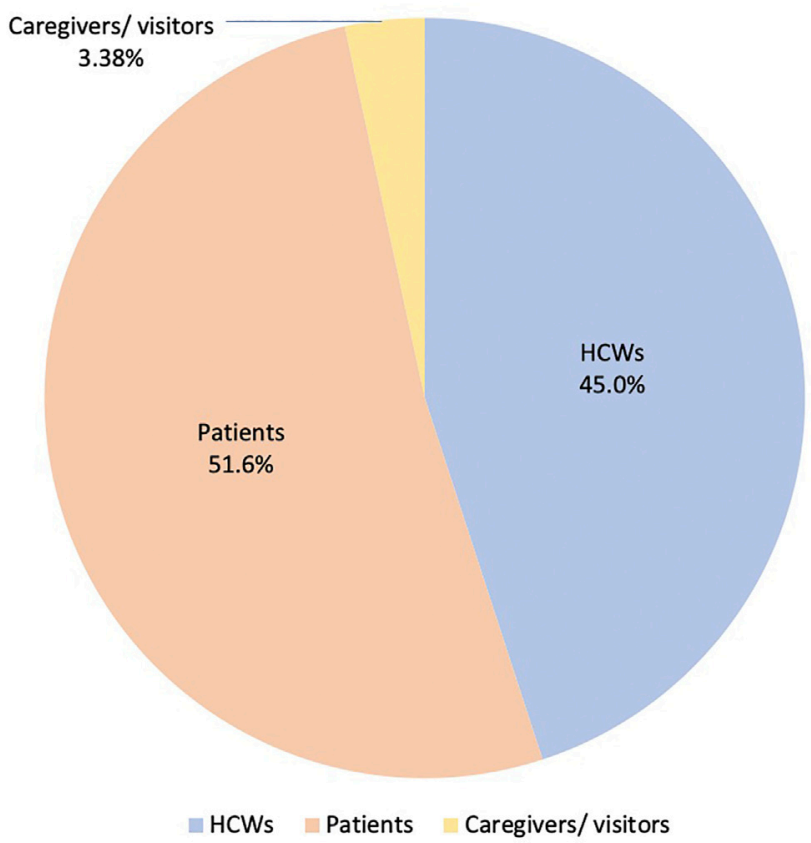

FIGURE 3 | Distribution of infected patients and healthcare workers (Singapore, 2021).

an outbreak and $1(2.86 \%)$ each from admission testing and travel testing. Only $6(17.1 \%)$ of the primary cases had reported prior contact with any COVID-19 positive individuals. The data is summarized in Figure 2. 


\section{Vulnerabilities in SARS-CoV-2 Hospital Outbreaks}

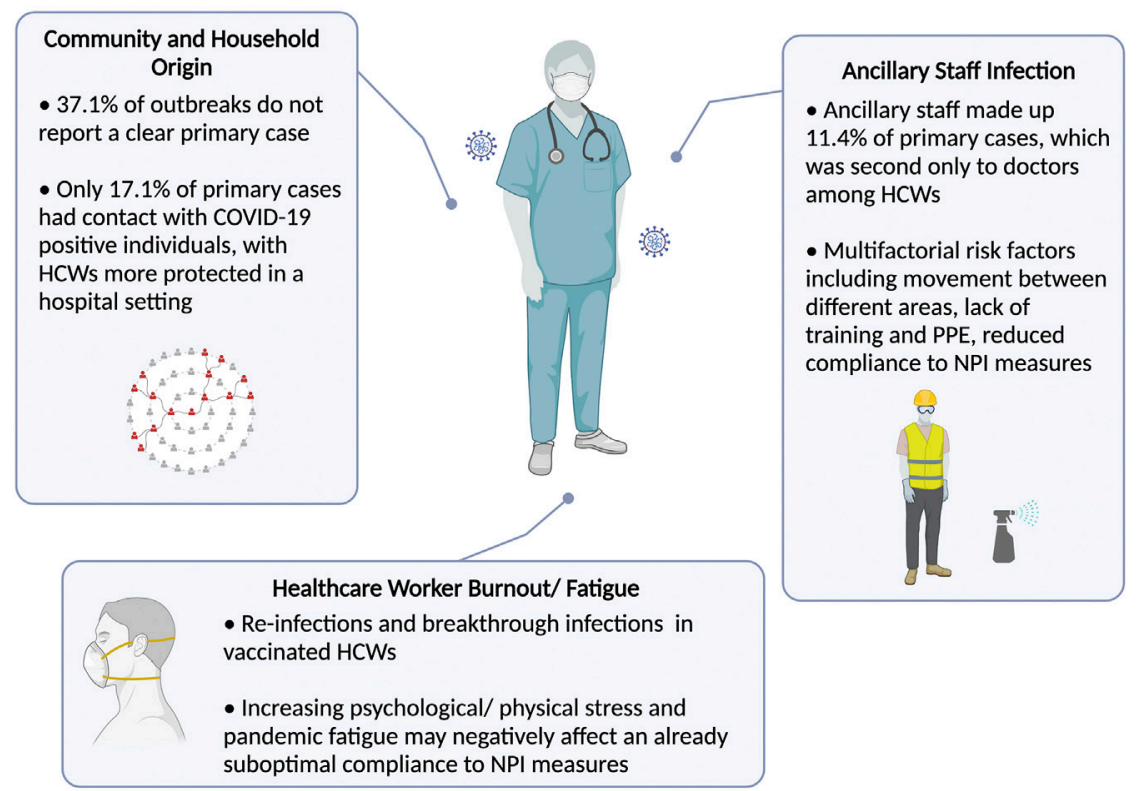

FIGURE 4 | Summary of identified vulnerabilities control leading to severe acute respiratory syndrome coronavirus 2 hospital outbreaks (Singapore, 2021).

\section{Infection Demographics}

Thirty-two outbreaks reported breakdowns of SARS-CoV-2 infection demographics, comprising 1,007 infected individuals. HCWs accounted for 453 (45.0\%) of total infected individuals, patients accounted for 520 (51.6\%) and the remaining 34 (3.38\%) comprised either caregivers or visitors, as presented in Figure 3.

\section{Attack and Mortality Rates}

Six outbreaks reported attack rate among HCWs (21.7 $\pm 17.4 \%)$, and 6 outbreaks reported attack rate among patients $(21.4 \pm$ 16.3\%). No HCWs died across 29 outbreaks reporting HCW mortality, while 28 outbreaks reported on patient mortality rate (15.0 \pm 20.7\%), summarized in Supplementary Table S2. Mortality rate was highest in an outbreak involving patients with underlying hematological disorders (50.0\%).

\section{DISCUSSION}

The current COVID-19 pandemic continues to strain healthcare systems worldwide. Despite better access to personal protective equipment and stringent hospital NPI measures, the risk of transmission in hospitals continues to beleaguer healthcare leaders and policymakers worldwide. This systematic review characterizes the pattern of hospital transmission and identifies important vulnerabilities in existing hospital preparedness against future infections. Data from this review highlight ancillary staff as primary cases of reported outbreaks, reverse transmission from the community and household contacts, and a resurgence of infections among HCWs despite vaccination and NPI measures (Figure 4).
A key observation from the current study is a significant predisposition of non-clinical ancillary staff working as cleaners, porters, housekeeping staff and healthcare assistants to developing SARS-CoV-2 infection. In the current review, ancillary staff formed the second largest group of HCW primary cases, second only to doctors. Although doctors, nurses and other frontline HCWs are closely scrutinized for PPE and NPI compliance [45], the critical roles played by ancillary staff in disrupting the chain of infection have received less attention. In contrast to the work environment of doctors and nurses that are regularly cleaned and decontaminated, the work areas of ancillary staff could vary substantially depending on their vocations. Some ancillary staff are involved in the transport of suspected or confirmed COVID19 patients, clean rooms of patients whose infection status were previously unknown, and share a communal area to rest and dine. Although ancillary staff made up of approximately $10 \%$ of primary HCW cases in the current study, these figures are also likely an underestimate as many articles do not specify the type of HCWs and consider occupational roles as either doctors, nurses and "other" healthcare staff. An increasing number of epidemiological studies have also reported not only a greater risk of infection but also highlighted ancillary staff as the main affected group within their cohorts [46-51] (Table 2). Several factors could explain increased propensity of ancillary staff to infection. For example, porters move between different spaces within hospital settings, including hospital wards, radiology diagnostic centers, emergency rooms and clinics, and have numerous contacts with patients and other HCWs. As services requiring ancillary staff are often contracted to external vendors, it is also not uncommon for cleaners and catering staff to rotate 
TABLE 2 | Epidemiological studies reporting ancillary staff as main group of COVID-19 healthcare worker infections (Singapore, 2021).

\begin{tabular}{|c|c|c|c|c|c|}
\hline Author & Year & Country & Design & $\begin{array}{l}\text { Cohort } \\
\text { size }\end{array}$ & Outcome \\
\hline Eyre et al. [46] & 2020 & United Kingdom & $\begin{array}{l}\text { Cross- } \\
\text { sectional }\end{array}$ & 10,034 & Porters and cleaners had the highest rates of infection (18.6\%) out of all occupational roles \\
\hline Shields et al. [47] & 2020 & United Kingdom & $\begin{array}{l}\text { Cross- } \\
\text { sectional }\end{array}$ & 545 & $\begin{array}{l}\text { Housekeeping staff were the largest group of seropositive HCWs }(34.5 \%) \text {, compared to } \\
14.8 \% \text { among those working in intensive care medicine }\end{array}$ \\
\hline Alkurt et al. [48] & 2021 & Turkey & $\begin{array}{l}\text { Cross- } \\
\text { sectional }\end{array}$ & 932 & Cleaning staff seropositivity rates $(6 \%)$ were highest among HCWs in 3 hospitals \\
\hline Wong et al. [49] & 2021 & Singapore & $\begin{array}{l}\text { Cross- } \\
\text { sectional }\end{array}$ & 5,050 & $\begin{array}{l}\text { Ancillary staff made up the biggest group (48.6\%) out of all locally acquired cases in Singapore } \\
\text { between January, } 23 \text { and April 17, } 2020\end{array}$ \\
\hline $\begin{array}{l}\text { Al-Kuwari } \\
\text { et al. [50] }\end{array}$ & 2021 & Qatar & $\begin{array}{l}\text { Cross- } \\
\text { sectional }\end{array}$ & 1,048 & $\begin{array}{l}\text { Storekeepers, engineering and maintenance staff, housekeeping staff, support staff, and } \\
\text { security staff had the highest infection rates of } 100,67.2,47.1,32.4 \text { and } 29.5 \% \text { respectively }\end{array}$ \\
\hline Dev et al. [51] & 2021 & India & Case-control & 3,100 & $\begin{array}{l}\text { Sanitation workers were at highest risk of infection [RR } 3.24 \text { (95\% Cl 2.05-5.12), p-value } \\
<0.0001]\end{array}$ \\
\hline
\end{tabular}

COVID-19, coronavirus disease 2019; HCW, healthcare worker.

through different environments and buildings, as reported in an outbreak involving a food service worker in an American hospital who worked in multiple settings [34]. Another report in Vietnam identified non-compliance to NPI measures among nonmedical staff contributing to an outbreak involving 27 catering staff, where a lack of training, personal protective supplies, and underestimation of virus transmission were cited as possible explanations [33]. Due to the more physical nature of their job, ancillary staff are also less likely to fully comply to PPE and are thus less protected. They may not be subject to adequate NPI training and the same scrutiny imposed on medical HCWs. Housekeeping staff and hospital cleaners too harbor increased risk of infection, as they are more likely to encounter contaminated surfaces [52]. One study reported lower rates of compliance to hand hygiene among non-medical HCWs [53].

With better understanding of the mechanics of viral transmission, hospitals have grown to be safer workplaces, compared to earlier in the pandemic where frontline HCWs were at significantly increased risk of infection [7]. Infection rates involving doctors and nurses have fallen substantially compared with those at the start of the pandemic. When the second wave of infections hit the United States in mid-2020, Baker et al. reported that out of a cohort of 10,275 HCWs, those who reported caring for patients with COVID-19 did not have increased risk of seropositivity [adjusted OR $(95 \% \mathrm{CI})=0.9(0.7-1.3)$ ] [54], suggesting that the risk of transmission from their daily work is low as a result of improved NPI measures. Data from this review, however, identify potential weak links for hospital outbreaks to be unlinked cases and the transmission of infection via asymptomatic primary HCWs not originating within the hospital. Close to $40 \%$ of hospital outbreaks did not report a clear primary case and most primary cases $(82.9 \%)$ did not have prior contact with COVID-19 positive patients. An earlier study in 2 Dutch hospitals also found $24 \%$ of infected HCWs had no patient contact at all and only $3.4 \%$ were exposed to a known inpatient with COVID-19 [55]. This is supported by results from viral sequencing among United States HCWs from 25 March to December 27, 2020 revealing that majority of infections were not linked to patients or co-workers and were instead genetically similar to viruses that were circulating in the community [56]. Among community settings, households in particular are higher risk settings where prolonged contact between household members could increase the likelihood of transmission. Furthermore, SARS-CoV-2 transmission is more likely in an indoor setting where the estimated household attack rate is $16.6 \%$, significantly higher than that of previous coronavirus outbreaks [57]. The risk of bringing SARS-CoV-2 infection from the household to the hospital was highlighted by hospital outbreaks in Germany and South Korea [35, 41]. Ran et al. reported early in the pandemic that HCWs in Wuhan with a diagnosed family member had a significantly increased risk of infection [RR $(95 \% \mathrm{CI})=2.76(95 \% \mathrm{CI} 2.02-3.77)]$ [58]. The risk of reverse transmission from the community and households could be compounded further by measures to self-isolate together with household members who share a common living environment and facilities (e.g., bathrooms) and in settings with uncontrolled community transmission. Central to reducing hospital outbreaks is also the control of community rates of transmission.

Despite compelling data supporting the overall efficacy of vaccination, breakthrough infections are known to occur due to various factors, including suboptimal production of antibodies, waning immunity and emergence of variant strains [59]. In Singapore and Taiwan, the emergence of more transmissible strains of the virus (e.g., Delta and Epsilon variant strains) had led to nosocomial spread of the SARS-CoV-2 virus even among vaccinated HCWs $[10,11]$. The rise in breakthrough infections may also be compounded by increasing pandemic fatigue among HCWs. A cross-sectional survey of 5 major cities observed decreased mask wearing and pandemic mitigation measures when declining incidence led to a lower perceived severity of COVID-19 [60]. Furthermore, as the pandemic progressed, HCWs have struggled with increased workload, longer working hours, prolonged states of heightened alert and restrictions in social mobility, with reports of increased depression, anxiety and stress stemming from fear and stress at the workplace as well as added stigma from the general public [61]. Apart from psychological implications, HCWs also face physical challenges from extended PPE usage. A systematic review of 14 studies estimated overall prevalence of PPE 
related adverse events to be $78 \%$ (95\% CI 66.7-87.5\%), including headache, dry skin and dyspnea [62]. Although poor wellbeing is commonly associated with medical errors and poorer patient safety outcomes [63], few studies have examined the possible link between burnout and compliance to NPI measures. Earlier in the pandemic, Zhou et al. found that increased burnout was negatively associated with hand hygiene in a study of 1,734 HCWs from 17 medical teams in Wuhan [64], corroborating pre-pandemic findings in a Greek hospital [65]. Despite playing a critical role, the pandemic has taken a toll on the mental wellbeing of HCWs which could compromise their adherence with NPI measures from work-related fatigue and burnout, compounding the already suboptimal compliance which led to $31.4 \%$ of the outbreaks in this review. This is especially important as HCWs often share common areas such as toilets, pantries and locker rooms [34]. These areas where NPI measures are likely to be less stringent could account for outbreaks where measures were supposedly well followed, leading to HCWs comprising $45.0 \%$ of infected individuals.

To implement NPI measures during severe outbreaks, HCWs should be allowed to isolate themselves from their families and the community, in temporary accommodation facilities that allow HCW to exercise physical distancing. Hotel facilities with staff cooperation and proper planning have been demonstrated to be viable options to house HCWs without the risk of SARS-CoV-2 spread [66]. Wang et al. also reported the effective use of face masks and disinfectants within households to reduce spread between family members [67], which can be applied when full isolation from potential household contacts is not possible. In these circumstances, pharmacological interventions such as povidone-iodine throat spray could be employed to reduce transmission risks to supplement NPI measures. In a largescale study involving residents living in a workers' dormitory, povidone-iodine throat spray was found to be associated with a $24 \%$ absolute risk reduction compared with an active comparator group who received oral vitamin C [68]. Measures to protect the safety of ancillary staff could define whether transmission involving HCWs could hinder the remarkable progress to lower HCW infection. Ancillary staff should be given the same intensity of NPI training as medical staff where personal protective supplies are adequate and their compliance to NPI measures is enforced. Engagement with healthcare workers to understand their views on policy and addressing practical issues such poor visibility from eye protection would aid in improving compliance [69]. Periodic surveillance using antigen rapid tests (ART) or polymerase chain reaction (PCR) tests could be implemented to facilitate early isolation. Although routine surveillance testing has not gained wide acceptance, these surveillance tests have identified asymptomatic cases that would have otherwise been missed, not just for HCWs but inpatients as well. Twice-weekly routine testing has been recommended in the setting of ongoing community transmission, though it has to be supplemented by NPI measures [70]. Studies have demonstrated the viability of maintaining high levels of compliance to regular screening in universities, where there is similarly shared accommodation and abundant interactions [71]. Retrospective investigation and open reporting of hospital outbreaks is also crucial, with $37.1 \%$ of outbreaks included in this review not reporting a clear primary case. The availability of additional data will allow for future studies to understand the pattern of infection chains and identify vulnerabilities in existing protocols. Vaccination remains imperative despite the emergence of new SARS-CoV2 strains, by substantially reducing viral loads in infected individuals and mitigating infectiousness [72]. Emerging data from Israel also reflect lower rates of COVID-19 and severe illness among the elderly after the administration of a booster vaccine dose [73].

Several limitations merit mention. First and most significantly, due to our search endpoint of July 27, 2021 the outbreaks included mostly included unvaccinated individuals, with many countries still working on vaccinating their populations. Since then, vaccination has been rolled out at different rates worldwide, with some countries offering different vaccine options. Although it is possible vaccination could alter transmission dynamics of the SARS-CoV-2 virus, the lessons gleaned from this review are likely to remain relevant and applicable to most healthcare settings especially with the emergence of more transmissible variants of concern, and the different availability and rates of booster vaccination among HCWs worldwide. Second, we relied on data from the published literature and did not systematically approach individual centers for the incidence of COVID-19 infection among their HCWs. This may lead to publication bias as attempts to report research findings towards the later part of the pandemic may not be favorably reviewed and accepted for publication. Third, there was significant heterogeneity when reporting HCW infections in ancillary staff which may understate the burden of infection in this segment of HCWs. Fourth, we only considered outbreaks in the hospital setting and did not examine primary care clinics or long-term care facilities such as nursing homes. Fifth, articles included in this review originated from high-income countries with adequate access to PPE supplies and good hospital infrastructure, and may not be generalizable to poor-resource healthcare settings. Sixth, only 4 of the papers reporting outbreaks described the use of genomic sequencing in establishing infection links, whereas ascertainment of primary cases for the remaining studies was based on traditional contact tracing which may not be definitive.

This systematic review highlights important learning points that elucidated on factors leading to outbreaks of SARS-CoV-2 infection in healthcare settings. Although there is a gradual shift towards considering COVID-19 as an endemic disease and economic considerations to loosen existing restrictions, active measures are needed to ensure patients can recover in a safe hospital environment without fear of contracting the virus. Caution should be exercised to prevent complacency with PPE measures to result in future hospital outbreaks as this could have devastating consequences to patients and the morale of HCWs [33]. Continuous efforts to train-retrain PPE measures especially among ancillary staff, encourage vaccination and implement regular routine screening will aid in detecting and stemming transmission of the virus early. The pandemic has exposed important vulnerabilities within healthcare systems which should be addressed before they are further exploited by the virus. 


\section{AUTHOR CONTRIBUTIONS}

$\mathrm{CN}, \mathrm{N}-\mathrm{AL}, \mathrm{LB}, \mathrm{AQ}$, and RS designed the study, developed the study protocol and tools and were responsible for data collection. $\mathrm{CN}$ and RS analyzed the data and wrote the manuscript. All authors contributed to the conceptualization of the research questions, interpretation of the results and manuscript writing. All authors read and approved the final manuscript.

\section{FUNDING}

The authors declare that this study received funding from the National Medical Research Council, Singapore (COVID19RF20052, CSA-SI/0003/2015). The funder was not involved in the study design, collection, analysis, interpretation of data, the writing of this article or the decision to submit it for publication.

\section{REFERENCES}

1. World Health Organization. WHO Coronavirus (COVID-19) Dashboard (2021). Available at: https://covid19.who.int/ (Accessed December 18, 2021).

2. Petersen E, Koopmans M, Go U, Hamer DH, Petrosillo N, Castelli F, et al. Comparing SARS-CoV-2 with SARS-CoV and Influenza Pandemics. Lancet Infect Dis (2020) 20:e238-e244. doi:10.1016/s1473-3099(20)30484-9

3. Tande AJ, Pollock BD, Shah ND, Farrugia G, Virk A, Swift M, et al. Impact of the Coronavirus Disease 2019 (COVID-19) Vaccine on Asymptomatic Infection Among Patients Undergoing Preprocedural COVID-19 Molecular Screening. Clin Infect Dis (2021) 74:59-65. doi:10.1093/cid/ciab229

4. Attaway AH, Scheraga RG, Bhimraj A, Biehl M, Hatipoğlu U. Severe Covid-19 Pneumonia: Pathogenesis and Clinical Management. Bmj (2021) 372:n436. doi:10.1136/bmj.n436

5. Cohen J, Rodgers YVDM. Contributing Factors to Personal Protective Equipment Shortages during the COVID-19 Pandemic. Prev Med (2020) 141:106263. doi:10.1016/j.ypmed.2020.106263

6. Chia ML, Him Chau DH, Lim KS, Yang Liu CW, Tan HK, Tan YR. Managing COVID-19 in a Novel, Rapidly Deployable Community Isolation Quarantine Facility. Ann Intern Med (2021) 174:247-51. doi:10.7326/m20-4746

7. Nguyen LH, Drew DA, Graham MS, Joshi AD, Guo CG, Ma W, et al. Risk of COVID-19 Among Front-Line Health-Care Workers and the General Community: a Prospective Cohort Study. Lancet Public Health (2020) 5: e475-e83. doi:10.1016/s2468-2667(20)30164-x

8. Kluger DM, Aizenbud Y, Jaffe A, Parisi F, Aizenbud L, Minsky-Fenick E, et al. Impact of Healthcare Worker Shift Scheduling on Workforce Preservation during the COVID-19 Pandemic. Infect Control Hosp Epidemiol (2020) 41: 1443-5. doi:10.1017/ice.2020.337

9. Varona JF, Madurga R, Peñalver F, Abarca E, Almirall C, Cruz M, et al. Seroprevalence of SARS-CoV-2 Antibodies in over 6000 Healthcare Workers in Spain. Int J Epidemiol (2021) 50:400-9. doi:10.1093/ije/dyaa277

10. Ministry of Health Singapore. Updates on Singapore's COVID-19 Situation (2021). Available at: https://www.moh.gov.sg/covid-19 (Accessed December 18, 2021).

11. Akhmetzhanov AR, Jung S-m., Cheng H-Y, Thompson RN. A HospitalRelated Outbreak of SARS-CoV-2 Associated with Variant Epsilon (B.1.429) in Taiwan: Transmission Potential and Outbreak Containment under Intensified Contact Tracing, January-February 2021. Int J Infect Dis (2021) 110:15-20. doi:10.1016/j.ijid.2021.06.028

12. Keehner J, Horton LE, Binkin NJ, Laurent LC, Pride D, Longhurst CA, et al. Resurgence of SARS-CoV-2 Infection in a Highly Vaccinated Health System Workforce. N Engl J Med (2021) 385:1330-2. doi:10.1056/NEJMc2112981

13. Bushman M, Kahn R, Taylor BP, Lipsitch M, Hanage WP. Population Impact of SARS-CoV-2 Variants with Enhanced Transmissibility And/or Partial Immune Escape. Cell (2021) 184:6229-42. doi:10.1016/j.cell.2021.11.026

\section{CONFLICT OF INTEREST}

The authors declare that the research was conducted in the absence of any commercial or financial relationships that could be construed as a potential conflict of interest.

\section{ACKNOWLEDGMENTS}

Figure 4 was created with BioRender.com.

\section{SUPPLEMENTARY MATERIAL}

The Supplementary Material for this article can be found online at: https://www.ssph-journal.org/articles/10.3389/phrs.2022.1604572/ full\#supplementary-material

14. Xiang B, Li P, Yang X, Zhong S, Manyande A, Feng M. The Impact of Novel Coronavirus SARS-CoV-2 Among Healthcare Workers in Hospitals: An Aerial Overview. Am J Infect Control (2020) 48:915-7. doi:10.1016/j.ajic. 2020.05.020

15. Perra N. Non-pharmaceutical Interventions during the COVID-19 Pandemic: A Review. Phys Rep (2021) 913:1-52. doi:10.1016/j.physrep.2021.02.001

16. Hall VJ, Foulkes S, Saei A, Andrews N, Oguti B, Charlett A, et al. COVID-19 Vaccine Coverage in Health-Care Workers in England and Effectiveness of BNT162b2 mRNA Vaccine against Infection (SIREN): a Prospective, Multicentre, Cohort Study. Lancet (2021) 397:1725-35. doi:10.1016/s01406736(21)00790-x

17. Page MJ, McKenzie JE, Bossuyt PM, Boutron I, Hoffmann TC, Mulrow CD, et al. The PRISMA 2020 Statement: an Updated Guideline for Reporting Systematic Reviews. Bmj (2021) 372:n71. doi:10.1136/bmj.n71

18. Team RCR. A Language and Environment for Statistical Computing. Vienna, Austria: R Foundation for Statistical Computing (2020).

19. Gao S, Yuan Y, Xiong Y, Zhang Y, Deng L, Chen T, et al. Two Outbreaks of SARS-CoV-2 in Department of Surgery in a Wuhan Hospital. Infect Prev Pract (2020) 2:100065. doi:10.1016/j.infpip.2020.100065

20. Ji H, Liu L, Huang T, Zhu Y. Nosocomial Infections in Psychiatric Hospitals during the COVID-19 Outbreak. Eur J Psychiatry (2020) 34:177-9. doi:10. 1016/j.ejpsy.2020.04.001

21. Kim SW, Jo SJ, Lee H, Oh JH, Lim J, Lee SH, et al. Containment of a Healthcare-Associated COVID-19 Outbreak in a university Hospital in Seoul, Korea: A Single-center Experience. PLoS One (2020) 15:e0237692. doi:10.1371/ journal.pone.0237692

22. Asad H, Johnston C, Blyth I, Holborow A, Bone A, Porter L, et al. Health Care Workers and Patients as Trojan Horses: a COVID19 ward Outbreak. Infect Prev Pract (2020) 2:100073. doi:10.1016/j.infpip.2020.100073

23. Schwierzeck V, König JC, Kühn J, Mellmann A, Correa-Martínez CL, Omran $\mathrm{H}$, et al. First Reported Nosocomial Outbreak of Severe Acute Respiratory Syndrome Coronavirus 2 in a Pediatric Dialysis Unit. Clin Infect Dis (2021) 72: 265-70. doi:10.1093/cid/ciaa491

24. Baker MA, Rhee C, Fiumara K, Bennett-Rizzo C, Tucker R, Williams SA, et al. COVID-19 Infections Among HCWs Exposed to a Patient with a Delayed Diagnosis of COVID-19. Infect Control Hosp Epidemiol (2020) 41:1075-6. doi:10.1017/ice.2020.256

25. Harada S, Uno S, Ando T, Iida M, Takano Y, Ishibashi Y, et al. Control of a Nosocomial Outbreak of COVID-19 in a University Hospital. Open Forum Infect Dis (2020) 7:ofaa512. doi:10.1093/ofid/ofaa512

26. Vanhems P, Saadatian-Elahi M, Chuzeville M, Marion E, Favrelle L, Hilliquin D, et al. Rapid Nosocomial Spread of SARS-CoV-2 in a French Geriatric Unit. Infect Control Hosp Epidemiol (2020) 41:866-7. doi:10.1017/ice.2020.99

27. Luong-Nguyen M, Hermand H, Abdalla S, Cabrit N, Hobeika C, Brouquet A, et al. Nosocomial Infection with SARS-Cov-2 within Departments of Digestive Surgery. J Visc Surg (2020) 157:S13-S18. doi:10.1016/j.jviscsurg.2020.04.016 
28. Rickman HM, Rampling T, Shaw K, Martinez-Garcia G, Hail L, Coen P, et al. Nosocomial Transmission of Coronavirus Disease 2019: A Retrospective Study of 66 Hospital-Acquired Cases in a London Teaching Hospital. Clin Infect Dis (2021) 72:690-3. doi:10.1093/cid/ciaa816

29. Jung J, Hong MJ, Kim EO, Lee J, Kim M-N, Kim S-H. Investigation of a Nosocomial Outbreak of Coronavirus Disease 2019 in a Paediatric ward in South Korea: Successful Control by Early Detection and Extensive Contact Tracing with Testing. Clin Microbiol Infect (2020) 26:1574-5. doi:10.1016/j. cmi.2020.06.021

30. Brandt MP, Jäger W, Epple S, Haferkamp A, Schröder A. SARS-CoV-2 Outbreak in Medical Employees in a Large Urologic Department: Spread, Containment and Outcome. Am J Infect Control (2021) 49:674-7. doi:10.1016/ j.ajic.2021.02.011

31. Schneider S, Piening B, Nouri-Pasovsky PA, Krüger AC, Gastmeier P, Aghdassi SJS. SARS-Coronavirus-2 Cases in Healthcare Workers May Not Regularly Originate from Patient Care: Lessons from a university Hospital on the Underestimated Risk of Healthcare Worker to Healthcare Worker Transmission. Antimicrob Resist Infect Control (2020) 9:192. doi:10.1186/ s13756-020-00848-w

32. Lessells R, Moosa Y, Oliveira TD. Report into a Nosocomial Outbreak of Coronavirus Disease 2019 (COVID-19) at Netcare St. Augustine's Hospital (2020). Available at: https://www.krisp.org.za/news.php?id=421 (Accessed December 18, 2021).

33. Duy C, Nong VM, Van Ngo A, Doan TT, Nguyen TQ, Truong PT, et al. Nosocomial Coronavirus Disease Outbreak Containment, Hanoi, Vietnam, March-April 2020. Emerg Infect Dis (2021) 27:10-7. doi:10.3201/eid2701. 202656

34. Hale M, Dayot A. Outbreak Investigation of COVID-19 in Hospital Food Service Workers. Am J Infect Control (2021) 49:396-7. doi:10.1016/j.ajic.2020. 08.011

35. Höring S, Fussen R, Neusser J, Kleines M, Laurentius T, Bollheimer LC, et al. Management of a Hospital-wide COVID-19 Outbreak Affecting Patients and Healthcare Workers. SN Compr Clin Med (2020) 2:2540-5. doi:10.1007/ s42399-020-00597-2

36. Biernat MM, Zińczuk A, Biernat P, Bogucka-Fedorczuk A, Kwiatkowski J, Kalicińska E, et al. Nosocomial Outbreak of SARS-CoV-2 Infection in a Haematological Unit - High Mortality Rate in Infected Patients with Haematologic Malignancies. J Clin Virol (2020) 130:104574. doi:10.1016/j. jcv.2020.104574

37. Borges V, Isidro J, Macedo F, Neves J, Silva L, Paiva M, et al. Nosocomial Outbreak of SARS-CoV-2 in a "Non-COVID-19" Hospital Ward: Virus Genome Sequencing as a Key Tool to Understand Cryptic Transmission. Viruses (2021) 13:604. doi:10.3390/v13040604

38. Dhakal R, O'Connell C, Gurung JB, Shah RP, Adhikari HP, Chandi N, et al. A Team Effort in Nepal: Experiences from Managing a Large COVID-19 Rehabilitation Hospital Outbreak. Spinal Cord Ser Cases (2021) 7:5. doi:10. 1038/s41394-020-00374-2

39. Klompas M, Baker MA, Rhee C, Tucker R, Fiumara K, Griesbach D, et al. A SARS-CoV-2 Cluster in an Acute Care Hospital. Ann Intern Med (2021) 174: 794-802. doi:10.7326/m20-7567

40. Selhorst P, Van Ierssel SH, Michiels J, Mariën J, Bartholomeeusen K, Dirinck E, et al. Symptomatic Severe Acute Respiratory Syndrome Coronavirus 2 Reinfection of a Healthcare Worker in a Belgian Nosocomial Outbreak Despite Primary Neutralizing Antibody Response. Clin Infect Dis (2020) 73:e2985-e2991. doi:10.1093/cid/ciaal850

41. Lee U, Kim SE, Lee SY, Wi HN, Choi O, Park J-W, et al. Source Analysis and Effective Control of a COVID-19 Outbreak in a University Teaching Hospital during a Period of Increasing Community Prevalence of COVID-19. J Korean Med Sci (2021) 36:e179. doi:10.3346/jkms.2021.36.e179

42. Cheng VC-C, Fung KS-C, Siu GK-H, Wong S-C, Cheng LS-K, Wong M-S, et al. Nosocomial Outbreak of Coronavirus Disease 2019 by Possible Airborne Transmission Leading to a Superspreading Event. Clin Infect Dis (2021) 73: e1356-e1364. doi:10.1093/cid/ciab313

43. World Health Organization. COVID-19 Situation Reports (2021). Available at: https://www.who.int/vietnam/emergencies/covid-19-in-vietnam/situation-reports (Accessed December 18, 2021).

44. Giesecke J. Primary and index Cases. The Lancet (2014) 384:2024. doi:10.1016/ s0140-6736(14)62331-x
45. Wiener-Well Y, Galuty M, Rudensky B, Schlesinger Y, Attias D, Yinnon AM. Nursing and Physician Attire as Possible Source of Nosocomial Infections. Am J Infect Control (2011) 39:555-9. doi:10.1016/j.ajic.2010.12.016

46. Eyre DW, Lumley SF, O’Donnell D, Campbell M, Sims E, Lawson E, et al. Differential Occupational Risks to Healthcare Workers from SARS-CoV-2 Observed during a Prospective Observational Study. Elife (2020) 9:9. doi:10. 7554/eLife.60675

47. Shields A, Faustini SE, Perez-Toledo M, Jossi S, Aldera E, Allen JD, et al. SARS$\mathrm{CoV}-2$ Seroprevalence and Asymptomatic Viral Carriage in Healthcare Workers: a Cross-Sectional Study. Thorax (2020) 75:1089-94. doi:10.1136/ thoraxjnl-2020-215414

48. Alkurt G, Murt A, Aydin Z, Tatli O, Agaoglu NB, Irvem A, et al. Seroprevalence of Coronavirus Disease 2019 (COVID-19) Among Health Care Workers from Three Pandemic Hospitals of Turkey. PLoS One (2021) 16:e0247865. doi:10.1371/journal.pone.0247865

49. Wong LY, Tan AL, Leo YS, Lee VJM, Toh MPHS. Healthcare Workers in Singapore Infected with COVID-19: 23 January-17 April 2020. Influenza Other Respi Viruses (2021) 15:218-26. doi:10.1111/irv.12803

50. Al-Kuwari MG, AbdulMalik MA, Al-Nuaimi AA, Abdulmajeed J, Al-Romaihi HE, Semaan S, et al. Epidemiology Characteristics of COVID-19 Infection Amongst Primary Health Care Workers in Qatar: March-October 2020. Front Public Health (2021) 9:679254. doi:10.3389/fpubh.2021.679254

51. Dev N, Meena RC, Gupta DK, Gupta N, Sankar J. Risk Factors and Frequency of COVID-19 Among Healthcare Workers at a Tertiary Care centre in India: a Case-Control Study. Trans R Soc Trop Med Hyg (2021) 115:551-6. doi:10. 1093/trstmh/trab047

52. Lan F-Y, Wei C-F, Hsu Y-T, Christiani DC, Kales SN. Work-related COVID19 Transmission in Six Asian Countries/areas: A Follow-Up Study. PLoS One (2020) 15:e0233588. doi:10.1371/journal.pone.0233588

53. Pirincci E, Altun B. An Analysis of Hospital Cleaning Staff s Attitudes and Conduct Regarding Hand hygiene and Cleaning. Int J Occup Saf Ergon (2016) 22:241-5. doi:10.1080/10803548.2015.1100906

54. Baker JM, Nelson KN, Overton E, Lopman BA, Lash TL, Photakis M, et al. Quantification of Occupational and Community Risk Factors for SARS-CoV-2 Seropositivity Among Health Care Workers in a Large U.S. Health Care System. Ann Intern Med (2021) 174:649-54. doi:10.7326/M20-7145

55. Kluytmans-van den Bergh MFQ, Buiting AGM, Pas SD, Bentvelsen RG, van den Bijllaardt W, van Oudheusden AJG, et al. Prevalence and Clinical Presentation of Health Care Workers with Symptoms of Coronavirus Disease 2019 in 2 Dutch Hospitals during an Early Phase of the Pandemic. JAMA Netw Open (2020) 3:e209673. doi:10.1001/jamanetworkopen.2020.9673

56. Braun KM, Moreno GK, Buys A, Somsen ED, Bobholz M, Accola MA, et al Viral Sequencing to Investigate Sources of SARS-CoV-2 Infection in US Healthcare Personnel. Clin Infect Dis (2021) 73:e1329-e1336. doi:10.1093/ cid/ciab281

57. Madewell ZJ, Yang Y, Longini IM, Jr., Halloran ME, Dean NE. Household Transmission of SARS-CoV-2. JAMA Netw Open (2020) 3:e2031756. doi:10. 1001/jamanetworkopen.2020.31756

58. Ran L, Chen X, Wang Y, Wu W, Zhang L, Tan X. Risk Factors of Healthcare Workers with Coronavirus Disease 2019: A Retrospective Cohort Study in a Designated Hospital of Wuhan in China. Clin Infect Dis (2020) 71:2218-21. doi:10.1093/cid/ciaa287

59. Bergwerk M, Gonen T, Lustig Y, Amit S, Lipsitch M, Cohen C, et al. Covid-19 Breakthrough Infections in Vaccinated Health Care Workers. N Engl J Med (2021) 385:1474-84. doi:10.1056/NEJMoa2109072

60. MacIntyre CR, Nguyen P-Y, Chughtai AA, Trent M, Gerber B, Steinhofel K, et al. Mask Use, Risk-Mitigation Behaviours and Pandemic Fatigue during the COVID-19 Pandemic in Five Cities in Australia, the UK and USA: A CrossSectional Survey. Int J Infect Dis (2021) 106:199-207. doi:10.1016/j.ijid.2021. 03.056

61. Cabarkapa S, Nadjidai SE, Murgier J, Ng CH. The Psychological Impact of COVID-19 and Other Viral Epidemics on Frontline Healthcare Workers and Ways to Address it: A Rapid Systematic Review. Brain Behav Immun - Health (2020) 8:100144. doi:10.1016/j.bbih.2020.100144

62. Galanis P, Vraka I, Fragkou D, Bilali A, Kaitelidou D. Impact of Personal Protective Equipment Use on Health Care Workers' Physical Health during the COVID-19 Pandemic: A Systematic Review and Meta-Analysis. Am J Infect Control (2021) 49:1305-15. doi:10.1016/j.ajic.2021.04.084 
63. Hall LH, Johnson J, Watt I, Tsipa A, O'Connor DB. Healthcare Staff Wellbeing, Burnout, and Patient Safety: A Systematic Review. PLoS One (2016) 11:e0159015. doi:10.1371/journal.pone.0159015

64. Zhou Q, Lai X, Wan Z, Zhang X, Tan L. Impact of Burnout, Secondary Traumatic Stress and Compassion Satisfaction on Hand hygiene of Healthcare Workers during the COVID-19 Pandemic. Nurs Open (2021) 8:2551-7. doi:10. $1002 /$ nop 2.786

65. Manomenidis G, Panagopoulou E, Montgomery A. Job Burnout Reduces Hand Hygiene Compliance Among Nursing Staff. J Patient Saf (2019) 15: e70-e73. doi:10.1097/pts.0000000000000435

66. Vimercati L, Tafuri S, Chironna M, Loconsole D, Fucilli FIM, Migliore G, et al. The COVID-19 Hotel for Healthcare Workers: an Italian Best Practice. J Hosp Infect (2020) 105:387-8. doi:10.1016/j.jhin.2020.05.018

67. Wang Y, Tian H, Zhang L, Zhang M, Guo D, Wu W, et al. Reduction of Secondary Transmission of SARS-CoV-2 in Households by Face Mask Use, Disinfection and Social Distancing: a Cohort Study in Beijing, China. BMJ Glob Health (2020) 5:e02794. doi:10.1136/bmjgh-2020-002794

68. Seet RCS, Quek AML, Ooi DSQ, Sengupta S, Lakshminarasappa SR, Koo CY, et al. Positive Impact of Oral Hydroxychloroquine and Povidone-Iodine Throat spray for COVID-19 Prophylaxis: An Open-Label Randomized Trial. Int J Infect Dis (2021) 106:314-22. doi:10.1016/j.ijid.2021.04.035

69. Wong EL-Y, Ho K-F, Dong D, Cheung AW-L, Yau PS-Y, Chan EY-Y, et al. Compliance with Standard Precautions and its Relationship with Views on Infection Control and Prevention Policy Among Healthcare Workers during COVID-19 Pandemic. Ijerph (2021) 18:3420. doi:10.3390/ijerph18073420
70. Chin ET, Huynh BQ, Chapman LAC, Murrill M, Basu S, Lo NC. Frequency of Routine Testing for Coronavirus Disease 2019 (COVID-19) in High-Risk Healthcare Environments to Reduce Outbreaks. Clin Infect Dis (2020) 73: e3127-e3129. doi:10.1093/cid/ciaa1383

71. Matheson NJ, Warne B, Weekes MP, Maxwell PH. Mass Testing of university Students for Covid-19. Bmj (2021) 375:n2388. doi:10.1136/ bmj.n2388

72. Levine-Tiefenbrun M, Yelin I, Katz R, Herzel E, Golan Z, Schreiber L, et al. Initial Report of Decreased SARS-CoV-2 Viral Load after Inoculation with the BNT162b2 Vaccine. Nat Med (2021) 27:790-2. doi:10.1038/s41591-02101316-7

73. Bar-On YM, Goldberg Y, Mandel M, Bodenheimer O, Freedman L, Kalkstein $\mathrm{N}$, et al. Protection of BNT162b2 Vaccine Booster against Covid-19 in Israel. N Engl J Med (2021) 385:1393-400. doi:10.1056/NEJMoa2114255

Copyright (C) $2022 \mathrm{Ng}$, Lim, Bao, Quek and Seet. This is an open-access article distributed under the terms of the Creative Commons Attribution License (CC BY). The use, distribution or reproduction in other forums is permitted, provided the original author(s) and the copyright owner(s) are credited and that the original publication in this journal is cited, in accordance with accepted academic practice. No use, distribution or reproduction is permitted which does not comply with these terms.

PHR is edited by the Swiss School of Public Health (SSPH+) in a partnership with the Association of Schools of Public Health of the European Region (ASPHER)+ 